\title{
An Investigation into Factors Affecting Hufi Students Poor English Performance: A Case Study of Non-English Major Third-Year Students at Ho Chi Minh University of Food Industry
}

\author{
Le Vu Ngan Ha 8 (D) \\ Faculty of Foreign Languages, Ho Chi Minh City University of Food Industry, Vietnam \\ $\triangle$ Corresponding Author: Le Vu Ngan Ha, E-mail: halvn@hufi.edu.vn
}

\section{ARTICLE INFORMATION ABSTRACT}

Received: May 08, 2021

Accepted: June 07, 2021

Volume: 3

Issue: 6

DOI: $10.32996 /$ jeltal.2021.3.6.4

\section{KEYWORDS}

English learning, performance, difficulty, factor, strategy, teaching methods, fundamental knowledge, practice English, language barriers.
It is undeniable that most students learning English as a foreign language at universities face many problems. This study was conducted to explore some reasons that impact HUFI students low English Learning. The subjects of this quantitative research were the third-year students in two classes-each respondent listed 10 reasons why students are poor in English performance. The study's findings revealed some primary factors, including firstly, the majority students stated that they were not confident enough to use English in class because of shyness and concern about making mistakes. Second, students lack fundamental knowledge and skills. Third, students do not have opportunities to practise English with native teachers because of big size classes. Fourth, students are not satisfied with some teachers' teaching methods. Last but not least, students are not well-motivated, encouraged and instructed to apply some effective learning strategies.

\section{Introduction}

According to Susanna (2007), English is used as an official language in many nations and influences many different cultures in a large number of countries; it is the central language of communication worldwide. The expansion of the English language has rapidly increased the needs to gain better communication English throughout the world because the aptitude to use English is very much needed for further studies, journeys in other countries as well as for social and professional global contacts of different kinds (Hashemi, 2011; Susanna, 2007). Ho Chi Minh City University of Food Industry (HUFI) is one of the key schools training technical workers of the industry (focusing on agricultural and food processing technology) for the region South. The university has 20 majors in technology, accounting, business administration, commerce and tourism. English is a compulsory subject for all students for the first two years. After 3 or 4 modules, students are expected to communicate in English, read basic English documents, and discuss simple issues with foreigners in their fields. However, most HUFI students have expressed stress, nervousness, or anxiety when using the English language. They have experienced some occasions when they have avoided communicating in the target language. This often has to do with the number of people present, the topic of conversation, and the formality of the circumstances. Many factors lead to HUFI students poor performance in their learning English as a foreign language, such as the overload of the curriculum in the limited time allowed, English teachers' methods, and lack of students' learning motivation. According to John and Ehow (2011), learning the English language derived from many different factors in different environments such as school resources, class size, quality of teachers, and the school attendance of learners. Murray and Christison (2010) observed that many students think English is only a school subject and they do not see its significance for their prospective employees to work with multinational or national companies where English is employed. As a person working in the education field and interested in this issue, the author begins researching reasons that impact HUFI students' low English Learning. This topic was identified as important to lecturers in providing them with the necessary directions for helping their students improve their English skills.

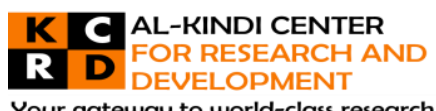

Your gateway to world-class research

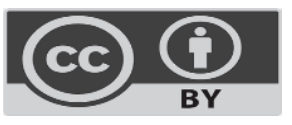

Published by Al-Kindi Center for Research and Development, United Kingdom. Copyright (c) the author(s). This open access article is distributed under a Creative Commons Attribution (CC-BY) 4.0 license 


\section{Literature Review}

There are a lot of determinants that contribute to the students' English learning outcomes. Those factors may derive from many components, including learning environment, teaching methods, internal motivation, etc.

\subsection{English learning environment}

Cora Lindsay with Paul Knigh (2006) says: "Learning can occur both inside and outside the classroom". That is true, it can be an informal process - picking up words from the TV, magazines, books, or friends, or it can be a formal process of attending lessons and taking part in classroom activities where language and skills are introduced and practised. Barry Sesnan (1997) added to the English learning process with the notion of learning by doing. It means that the teacher must give the students as many opportunities as possible to use English outside the classroom. This, in turn, means that the English taught should be immediately useful to the students and that the exercises done in class should be on words and expressions which the students can use themselves if they meet an English - speaker on their way home from school. From the earliest stages of reading, the students should be taught to read the words which they see around them on noticeboards, on lorries, and on buses. They should be taught to look at every possible example of written English and try to read it. Nevertheless, Fema (2003) held the view that students' mother tongue can contribute to their errors in using English and English is only used in classes. Students have no chance to communicate with native people in English

\subsection{Teachers' teaching methods}

Obviously, teachers play a crucial role in students' language acquisition process. Cora Lindsay with Paul Knigh (2006) was of the view that the teachers' job is to help learners learn. This relates both to the formal classroom process and learning outside the classroom. Undoubtedly, teachers are responsible for a large amount of what happens in the classroom - what is taught, the resources used, the type and order of activities, classroom management, assessment, feedback, correction, and so on. It is also part of the teacher's job to encourage learners to take responsibility for their own learning and become active learners. Cora Lindsay with Paul Knigh (2006) also added that teachers should become aware of factors that affect language learning, such as learner types, age, etc. However, the majority of English teachers do not consider the students' background, age, and major in choosing the suitable method in teaching, which affects the students' outcomes. Therefore, it is clear that teachers' inability to use proper teaching methods contributes to poor English language learning among HUFI students.

Besides, Jere Brophy (2010) stated that when teachers teach the right things the right way, motivation takes care of itself. If students are not enjoying learning, something is wrong with the teachers' curriculum and instruction-They have somehow turned an inherently enjoyable activity into drudgery.

\subsection{Motivation.}

The author has heard people saying, "between success and failure. If they are motivated, they will learn, and if not, they won't". So what is motivation? How would the motivation be defined? Douglas Brown (2000) drew motivation definition from many different sources: Motivation is the extent to which you make choices about (a) goal to pursue and (b) the effort you will devote to that pursuit.

According to Cora Lindsay with Paul Knigh (2006), "Motivation can be analyzed in terms of whether it is intrinsic or extrinsic". Back to the time of 1970, Abraham Maslow claimed that intrinsic motivation is clearly superior to extrinsic. Intrinsic motivation refers to the individual learner's wish to learn or enjoyment in learning, whereas extrinsic motivation to a learner's need to learn because of external factors such as employment, social pressure, academic requirements, and so on. A mismatch between the two, i.e. someone who has to learn but does not want to, can create problems and lead to ineffective learning. In this study, the researcher wants to focus on intrinsic motivation, which is believed to play more important to the learners' achievements in learning English.

\section{Methodology}

To find out non-English major third-year students' problems in English performance and underlying elements contributing to students' lack of fluency and proficiency in English. Two English 2 classes at HUFI, each consisting of about 50 students, were compared. They are from different majors but all have passed English A0, A1, A2 and B1 with Life A1-A2 and A2-B1 course books. In these English 2 classes, most of them have finished English B1 with Life A2-B1 from Unit 1 to 6 . The English B2 subject is also selected from the LIFE book - A2-B1 from Unit 7 to 12. Students in a class are divided into 7 groups with 7 or 8 persons each.

Since the present study focuses on the reasons impacting the students' performance, it is important to elicit students' responses on the learning environment, teachers' methods and self-motivation in English B2 classes. Students were briefed that their responses are meant for research purposes and not related to their evaluation process. No personal identifying information was obtained. The students were informed that their participation in the study was voluntary. 
A quantitative method was used to address and explore research questions. A questionnaire was designed to obtain students' feedback on challenges in using English in 2-B2 classes at HUFI. A checklist of possible barriers was used to elicit students' responses. The students were given 6 questions regarding difficulties related to students' internal factors in English performance and 6 questions relating to external factors referring to how the lecturers have taught them. The questionnaires were distributed to all students in two English B2 classes, consisting of 51 female students and 45 male ones. Most of them from accounting and biotechnology majors had 15 minutes to choose the answers that indicate their subjective opinions about the target language have been transferred over the past 3 courses. Students were encouraged to seek researcher's help whenever they found a given question difficult to understand.

\section{Findings and Analysis}

It seems to me that the purpose of the study, which finds out factors that affect HUFI students' low performance, has captured most students' concern. They were eager to answers the questions given. One hundred twenty-seven students participated in the study. $53 \%$ was female students and $47 \%$ was male ones.

\subsection{Difficulties relating to the English learning environment.}

The table below shows the elements as the students' challenges in their English learning environment.

\begin{tabular}{|l|l|l|l|l|}
\hline No. & How often do you use English? & $\begin{array}{l}\text { Agree } \\
(\%)\end{array}$ & $\begin{array}{l}\text { Not sure } \\
(\%)\end{array}$ & $\begin{array}{l}\text { Disagree } \\
(\%)\end{array}$ \\
\hline 1. & $\begin{array}{l}\text { I give myself as much opportunity as possible to encounter new } \\
\text { language. }\end{array}$ & 3,1 & 46,9 & 50 \\
\hline 2. & I use the new language as much as possible outside the classroom & 6,3 & 49 & 44,8 \\
\hline 3. & I take every opportunity to practise the four skills. & 1 & 31,3 & 66,7 \\
\hline 4. & I have confidence in myself and my ability to learn English. & 32,3 & 28,1 & 39,6 \\
\hline 5. & I use the new language just inside the classroom. & 57,3 & 40,6 & 2,1 \\
\hline
\end{tabular}

Table 1. Difficulties relating to English learning environment

The table above shows the frequency students use English inside and outside. It is easily seen that most students - $50 \%$ percent of them - do not give themselves as many opportunities as possible to encounter a new language. Only 6,3 percent of students use the new language as much as possible outside the classroom. In addition, more than a half - roughly 67 percent of respondents - hardly ever take every opportunity to practise the four skills. As we can see from the table, the majority of them use the new language just inside the classroom. However, the number of not sure and disagree participants is quite high, about 40,6 percent and 2,1 percent respectively.

\subsection{Teachers' teaching methods.}

The questions and data below indicate how the students have been satisfied with the teachers' method since their first year studying English in HUFI.

1. How clear are the course objectives the teacher offered?

$\begin{array}{ll}\text { a. Very clear } & 5,2 \% \\ \text { b. Somewhat clear } & 24 \% \\ \text { c. Neutral } & 60,4 \% \\ \text { d. Unclear } & 8,3 \% \\ \text { e. Very unclear } & 2,1 \%\end{array}$

2. Are you satisfied with the quality of teaching?

a. Very satisfied $\quad 1 \%$

b. Somewhat satisfied $\quad 43,4 \%$

c. Neutral $\quad 48 \%$

d. Dissatisfied $\quad 3,1 \%$

e. Highly dissatisfied $\quad 4,2 \%$

Reasons (optional)

3. Are you active or encouraged to take part in activities in the classroom?

a. Yes $\quad 45,8 \%$

b. No $\quad 54,2 \%$

Reasons (optional) 
4. Do you feel that the teacher is preparing you adequately for your communication with others in English?

a. Yes $82,3 \%$

b. No $\quad 17,7 \%$

Figure 1. Student satisfaction about the teachers' teaching methods

Figure 1 demonstrates the level of student satisfaction with the teachers' methods. It is clear that most of the students are not clear about the course objectives provided by the teachers, about $70 \%$. Although nearly a half (48\%) of respondents have no idea about the quality of teaching, the number of satisfied people is much higher than that of dissatisfied ones, about $44 \%$ and $7 \%$ accordingly. Nevertheless, about half of students actively participate in classroom activities, roughly $46 \%$. Besides, the majority of participants do not get benefits from the lessons. They do not feel that the teacher is preparing them adequately for their communication with others in English.

Questions 2,3 also asks about the reasons for the students' choices about the teacher quality and how much they help students get involved in the lesson in classes. Talking about teachers' quality, 8 students are sensitive about the teachers' ability and aptitudes. Those respondents think that the teachers cannot speak English well, especially some teachers for the Philipines. 14 of the students said that the teachers have good knowledge and skills in the language. 17 students talked about their teachers' attitude, and they thought that the teachers have positive attitudes towards students' mistakes, proficiency and ability which are necessary to enhance students' performance. 7 surveyors chose the answers of $d$ and e from question 2 which are "dissatisfied" and "highly dissatisfied" but they do not give any more information. However, 23 participants expressed their disappointment about the class size, which is considered quite crowded, making it hard for the teacher to get to know all students' problems in learning English.

\subsection{Motivation}

The table below shows the students'motivation elements in their English learning.

\begin{tabular}{|l|l|l|l|}
\hline No. & Descriptions of your English Learning Motivation & $\begin{array}{l}\text { Agree } \\
(\%)\end{array}$ & $\begin{array}{l}\text { Disagree } \\
(\%)\end{array}$ \\
\hline 1. & $\begin{array}{l}\text { Earning a university degree and getting a job are more } \\
\text { important to me than learning English. }\end{array}$ & 34,4 & 65,6 \\
\hline 2. & $\begin{array}{l}\text { I mainly focus on using English for class } \\
\text { assignment and the exams. }\end{array}$ & 82,3 & 17,2 \\
\hline 3. & $\begin{array}{l}\text { Being proficient in English can lead to more } \\
\text { success and achievements in life. }\end{array}$ & 79,2 & 20,8 \\
\hline 4. & Learning English can help me have more foreign friends. & 40,6 & 59.4 \\
\hline 5. & Being proficient in English can boost my own value & 81,3 & 18.7 \\
\hline 6. & I only study English when required. & $75 \%$ & $25 \%$ \\
\hline
\end{tabular}

Table 2. Motivation elements in their English learning

Table 2 reveals the surveyors' intrinsic motivation in learning English. Obviously, the respondents do not possess a high level of motivation to learn English. This is shown clearly by the percent of $65,6 \%$ of them who are on the view that earning a university degree and getting a job is more important to me than learning English. Although statement number 5 (Being proficient in English can boost my own value) has the highest percent, $81,3 \%$ about the advantages of being proficient in English and $79,2 \%$ of the participants hold the view that being proficient in English can lead to more success and achievements in life. However, the majority of respondents, up to $82,3 \%$, mainly focus on using English for class assignment and exams and $75 \%$ of surveyors only study English when required.

\section{Discussion}

Findings of the study have pointed out that the lack of an English environment is one of the most critical factors associated with students' poor performance in Ho Chi Minh City University of Food Industry. Language competence is improved through active and frequent use. The data show that what Barry Sesnan (1997) said is definite. Students should be provided with maximum English exposure as well as meaningful and purposeful activities through which they can learn and apply the language. Therefore, a rich English language practising environment can be created by taking full advantage of the time and resources inside and outside the classroom. The university should offer students more opportunities to use English like setting up an English lobby with a variety of English resource materials, organizing regularly English extra-curricular activities, e.g., speeches in English by guest speakers from different English accents or shows performed in English English club in the campus. 
In addition, the findings also support the idea that teacher quality is a matter of student achievement. The majority of the respondents value their instructors' friendliness and good listeners to the learners' problems. This finding is similar to that of Cora Lindsay with Paul Knight (2006). Furthermore, class size reduces the student-teacher ratio. Participant needs more chances to communicate with the foreign teachers which benefits a lot for their language acquisition. The researcher also notices that student acquire the language knowledge much more easily when the lecturers deliver academic objective by making clear for students what to expect and how much specific time allocated. Lecturers should be flexible to use teaching management strategies in order to maximize learners' involvement rates.

Findings of this research indicate that these HUFl students were not affected much by intrinsic motivation such as enhancing personal value, having more job openings, etc. The high percentage of the number of the participants who mainly focus on using English for a class assignment and the exams indicates that they do not learn the English language to reach mastery of English. The results proved that what Abraham Maslow (1970) said is true. As an English lecturer, the researcher also finds out that a mismatch between the two types of motivation, i.e., someone who has to learn but does not want to, can create problems and lead to ineffective learning. Furthermore, because the methods of student performance evaluation in HUFI are based upon grades, the goal of students is to attain high grades rather than explore ideas or personal knowledge. Therefore, Razieh Shaikholeslami and Mohammad Khayyer (2006) were of the view that students who try to achieve high grades may show lower motivation for knowledge development.

\section{Conclusion}

The main purpose of this study was to find out the reasons that affect students' low English competence as a foreign language. The students' poor performance in HUFI has been a source of concern to most Vietnamese recruiters. The question, "why most HUFI students find it difficult to use English, " was employed in this study to investigate the English students' perceptions of their poor English language performance learning. The current study with non-English major third-year students shows that the factors affecting their low performances in English caused dominantly by three factors, namely learning environment (inside and outside), teachers' method, and intrinsic and extrinsic motivation. Regarding the learning environment related to both inside and outside the classroom, it is considered inadequate to enhance students' language skills due to students' lack of vocabulary and English learning strategies, limited communication with native teachers, and limited English-speaking environment. As for teachers' quality which is the most important school-related factor influencing student achievement, the study has found a positive effect on teacher characteristics. Yet, their teaching effectiveness has not reached the expected point. Students need more from the teachers to offer their learners more practical knowledge and more chances to get involved in the lesson and communicate with foreign teachers. In addition, students acquire the language knowledge much more easily when the lecturers deliver academic objective by making clear for students what to expect and how much specific time allocated. Lecturers should be flexible to use teaching management strategies in order to maximize learners' involvement rates. Other factors in intrinsic motivation surprisingly dominate it because most respondents valued the vital role of English for their career and life quality, but what they have done does not contribute to their future. The majority of the participants concentrate on studying English for class assignments and exams. They do not learn the English language to reach proficiency in English.

To the researchers, these results can have very practical implications for the language teachers in HUFI. When attempting to determine these factors, lecturers can do more research on techniques that help HUFI students improve their language proficiency and activate their intrinsic motivation. However, it can be said that one of the limitations of this research is that the 96 surveyors are from different majors. They cannot represent all students in their majors. The specific factors affecting students' low English performance of each major should be confirmed in another study.

Funding: This research received no external funding.

Acknowledgements: the completion of this research paper could not have been accomplished without the support of the board of management in HUFI Faculty of Foreign Languages and my students' participation. Their contributions are sincerely appreciated and gratefully acknowledged.

Conflicts of Interest: The authors declare no conflict of interest.

\section{References}

[1] John, L., \& Ehow, C. (2011). Factors Affecting quality of English language Teaching and Learning. Retrieved 15/05/21 from http://www.ehow.com/info 8040040 factors-english-language-teaching-learning.html

[2] Hashemi, M. (2011). Language Stress And Anxiety Among The English Language Learners. Procedia - Social and Behavioral Sciences, 30(0), 1811-1816. Retrieved 15/05/21 from http://dx.doi.org/10.1016/j.sbspro.2011.10.349

[3] Razieh, S \& Mohammad, K (2006). Intrinsic motivation, extrinsic motivation, and

Learning english as a foreign language. Retrieved 20/05/21 from https://doi.org/10.2466/PR0.99.3.813-818 
[4] Abraham, M (1970). Motivation and Personality. Retrieved 20/05/21 from https://books.google.com.vn/books?hl=vi\&lr=\&id=DVmxDwAAQBAJ\&oi=fnd\&pg=PR8\&dq=abraham + maslow+1970+motivation+and + person

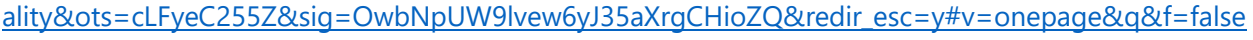

[5] Fema, B. M. (2003). Problem of Teaching English Language in NCE Programme. In Azare Journal of Education.

[6] Jere Prophy (2010) Motivating Students to Learn. Routledge

[7] Murray, D. E., \& Christison, M. A. (2010). What English Language Teachers Need to Know: Understanding Learning. Taylor \& Francis.

[8] Cora, L \& Paul, K. (2006). Learning and Teaching English. Oxford

[9] Susanna, A. (2007). The weak language learner: a study of ways of taking weak language learners into consideration in class. Sweden: Vaxjo University, School of Humanities English, GIX115. 